УДК 556.04

\title{
МАРКЁРЫ БИОГЕОХИМИЧЕСКОГО МОНИТОРИНГА В РАЙОНЕ ХВОСТОХРАНИЛИЩА СУЛЬФИДНЫХ РУД
}

\author{
Турбинский Виктор Владиславович1, \\ vvturbinski@mail.ru
}

\section{Бортникова Светлана Борисовна², BortnikovaSB@ipgg.sbras.ru
Никифорова Наталья Германовна', natnik@ngs.ru

\author{
Айзман Роман Иделевич4, \\ aizman.roman@yandex.ru
}
Корнеева Татьяна Владимировна², korneevatv@ipgg.sbras.ru

Франовский Сергей Юрьевич 5 , franovsky.sergey@gmail.com

\section{Огудов Александр Степанович 3 , ogudov.tox@yandex.ru}

1 Новосибирский государственный медицинский университет Минздрава России, Россия, 630091, г. Новосибирск, Красный проспект, 52.

2 Институт нефтегазовой геологии и геофизики им. А.А. Трофиммука Сибирского отделения Российской академии наук, Россия, 630090, г. Новосибирск, пр. Академика Коптюга, 3.

3 Новосибирский научно-исследовательский институт гигиены Роспотребнадзора, Россия, 630108, г. Новосибирск, ул. Пархоменко, 7.

4 Новосибирский государственный педагогический университет, Россия, 630126, г. Новосибирск, ул. Вилюйская, 28.

5 Московский государственный университет им. М.В. Ломоносова, Россия, 119991, г. Москва, гСП-1, Ленинские горы, 1, стр. 12.

\begin{abstract}
Актуальность. Хвостохранилища горнодобывающих предприятий являются источниками загрязнений окружающей среды химическими элементами и служат существенным фактом риска для хозяйственно-питьевого водопользования и здоровья населения. На примере воды гидроотвала на хвостохранилище в пос. Комсомольск (Кемеровская обл.), вмещающего отходы цианирования золото-арсенопирит-кварцевых руд, показано воздействие мышьяка и сурьмы на организмы теплокровных животных.

Цель: обоснование маркёров мониторинга окружающей среды и теплокровных организмов в условиях риска воздействия хвостохранилища отходов обогащения сульфидных руд.

Методы исследования включали в себя отбор проб воды из гидроотвала с иелью перорального введения экспериментальным животным (самцы белых крыс линии Вистар с массой тела 250-290 г). Воду анализировали на ряд химических элементов методом ICP-AES. Далее после препарирования животных определяли элементный состав тканей. Анализ осуществлялся методом РФА-СИ на станции элементного анализа VEPP-3 (ИЯФ СО РАН). Обработка эмиссионных спектров производилась с помощью программы AXIL.

Результаты. По данным элементного состава тканей органов - печени, почек, сердиа, лёгких, щитовидной железы, крови, мочи и кала - самцов белых крыс линии Вистар обоснованы маркёры экспозиции комбинированного действия сурьмы (42-61 мке/ке/сут) и мышьяка (10,0-15,0 мке/кг/сут). Установлено, что воздействие сурьмы и мышьяка в исследуемых дозах приводит как к их накоплению в тканях органов животных, так и к изменению баланса $\mathrm{Zn}, \mathrm{Cu}, \mathrm{Fe}, \mathrm{Mn}, \mathrm{Sr}, \mathrm{Ni}, \mathrm{Pb}$. Paccчитаны коэфрфициенты абсорбции и элиминации As и Sb для тканей внутренних органов при пероральном поступлении в организм, а также показана корреляция между содержанием As и другими элементами в органах экспериментальных животных в разные сроки эксперимента как маркёры реакции организма.
\end{abstract}

\section{Ключевые слова:}

Сульфридные руды, хвостохранилища, дренажные воды, сурьма, мышьяк, питьевая вода, ткани органов, константа абсорбции, константа элиминации.

\section{Введение}

Проблема влияния кислых дренажных вод с мест складирования отходов переработки руд на водные объекты является многие годы предметом исследователей [1-5]. Установлено, что попадание рудных и примесных элементов в окружающую природную среду сопровождается образованием техногенных биогеохимических провинций, опасных для животных, растений и здоровья населения. Эта опасность может проявляться на значительном удалении от складированных отходов [6-10]. Токсическому воздействию подвержены буквально все представители биосферы [11], а сложный состав токсичных элементов в каждом хвостохранилище образует индивидуальные свойства токсичности, не поддающиеся расчётному прогнозированию, и нуждающиеся в экспериментальном обосновании [12].

Биогеохимические условия горнорудного производства служат и предметом междисциплинарных исследований [13-15]. Использование новых методов 
биогеохимической индикации позволяет изучить специфические реакции растений и животных на изменение содержания микроэлементов - $\mathrm{Pb}, \mathrm{Cd}, \mathrm{Cu}, \mathrm{Zn}$ и As, в почвах и организмах по сравнению с фоновыми территориями. Выявлена активизация синтеза серосодержащих веществ в листьях ивы, облепихи и матьи-мачехи при максимальном содержании тяжелых металлов в почвах [16]. Определение адаптационной изменчивости систем организма в условиях геохимических аномалий среды обитания человека является необходимым условием выработки эффективных мер по профилактике нарушений здоровья населения, проживающего на территориях биогеохимических провинций [17-20].

Цель данного исследования заключалась в обосновании маркёров мониторинга окружающей среды и теплокровных организмов в условиях риска воздействия хвостохранилища отходов обогащения сульфидных руд.

Для достижения поставленной цели решались следующие задачи: 1) определение изменения элементного состава тканей органов белых крыс линии Вистар при пероральном поступлении воды из гидроотвала Комсомольского хвостохранилища; 2) гигиеническая оценка риска для здоровья населения в результате загрязнения подземных источников питьевого водоснабжения фильтрационными водами с территории хвостохранилища; 3) обоснование маркёров биогеохимического мониторинга.

\section{Объекты, материалы и методы исследований}

Исследование было проведено применительно к хранилищу отходов цианирования золотоарсенопирит-кварцевых руд (рис. 1), расположенному в пос. Комсомольский (Кемеровская обл.). Хвостохранилище представляет собой естественную котловину, заполнявшуюся с 1964 г. общим стоком золото- извлекательного завода. Площадь хвостохранилища 146 тыс. м², объем около 810 тыс м ${ }^{3}$. Количество накопленного материала около 1,1 млн м³. С трех сторон оно ограждено рельефом, а с четвертой - насыпной дамбой. В результате складирования отходов над поверхностью твердой части (составляющей около 3,5 млн т) образовалось техногенное озеро, площадь которого около 60 тыс. м² и средняя глубина около 2 м. Оно пополнялось за счет поступления технологических растворов, представляющих собой отходы золотоизвлекательного завода, а после его остановки, в 1999 г., - сезонными осадками [21, 22]. Хвостохранилище расположено в черте населённого пункта - пос. Комсомольск, и гидроотвал, со временем превратившийся в своеобразное техногенное озеро, активно используется местным населением в хозяйственнобытовых целях: в летний период в нём купаются дети, пасётся домашний скот, жители посёлка вылавливают рыбу и на берегах устраивают пикники.

Предыдущими исследованиями было показано, что высокоминерализованные растворы из хвостохранилища просачиваются по природному разлому на глубине 20 м и поступают в горизонты подземных вод, являющиеся источником питьевого водоснабжения посёлка [22]. В результате в подземной воде из скважины питьевого водоснабжения пос. Комсомольский по ул. К. Маркса содержание мышьяка почти в 10 раз превышало предельно допустимую концентрацию [23], а в подземной воде из скважины питьевого водоснабжения по ул. Восточная приближалось к предельно допустимому. Эти обстоятельства: использование гидроотвала в качестве мест отдыха и опасные концентрации мышьяка в питьевых водах, определили необходимость проведения токсикологогигиенического исследования влияния этих вод на организмы теплокровных животных.
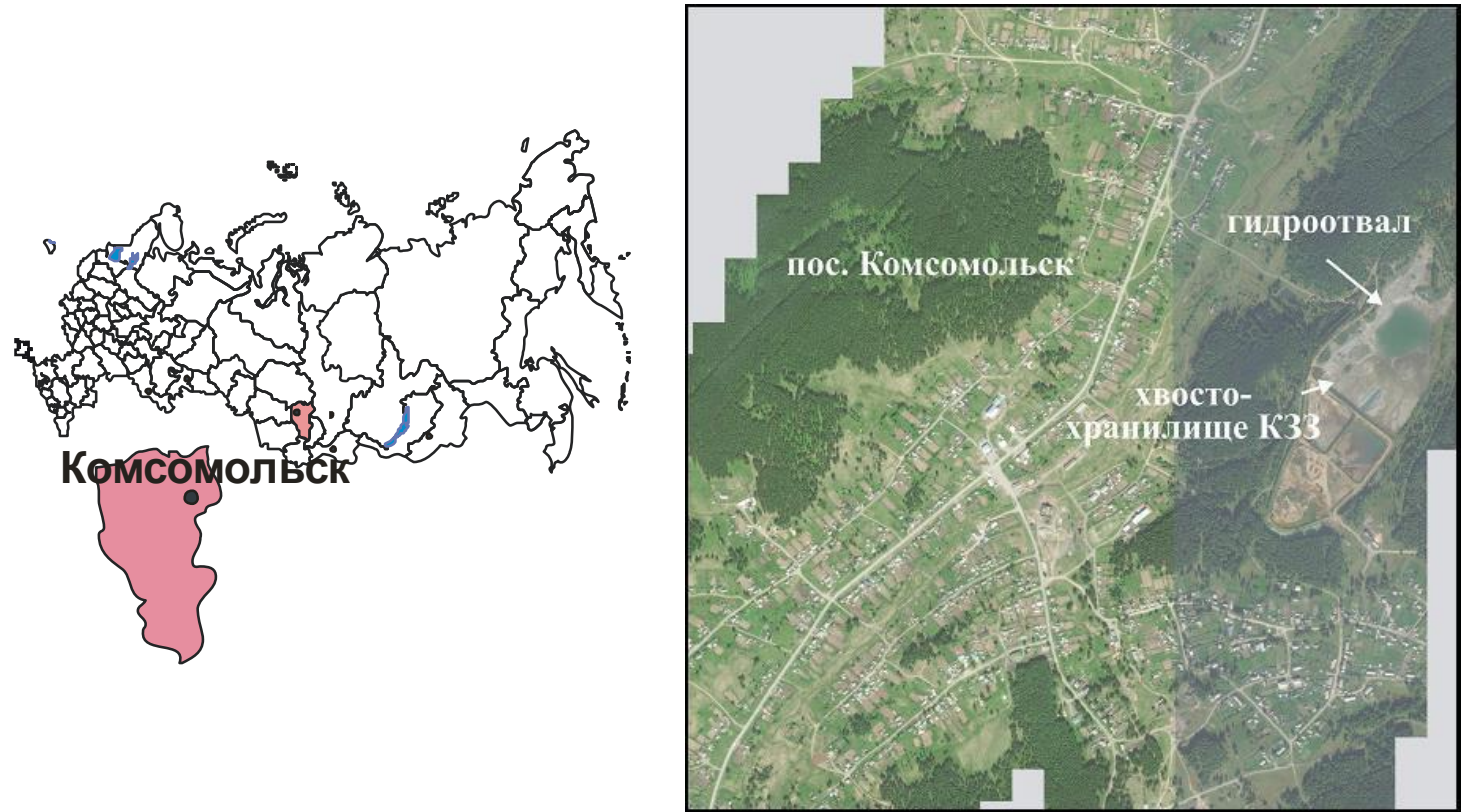

Pис. 1. Географическое положение объекта исследования и космоснимок расположения хвостохранилища

Fig. 1. Geographic location of the object of study and the satellite image of the tailings location 
Для проведения экспериментов с лабораторными животными была взята вода из гидроотвала (50 л), в которой, согласно предыдущим оценкам [21, 22], концентрации мышьяка и сурьмы существенно превышали ПДКхпн [23]. Для периода восстановления после затравки использовалась водопроводная вода г. Новосибирска.

В воде для экспериментов (из гидроотвала и водопровода) были определены концентрации химических элементов в ИНХ СО РАН (аналитик О.В. Шуваева) методом ICP-AES, прибор IRIS фирмы Jarell Ash Corporation (США), ошибка определения составляет $5-10 \%$.

Схема экспериментов была следующая. Животные (самцы белых крыс линии Вистар с массой тела 250 290 г) были разделены на две группы: опытную и контрольную, для каждого этапа эксперимента.

Контрольная группа животных получала из поилок водопроводную питьевую воду.

Опытная группа животных получала для питья воду из гидроотвала (1 и 2 этапы):

- на первом этапе в течение 1 недели, после чего были отобраны и препарированы 4 животных;

- на втором этапе в течение следующих 2-х недель животные пили ту же воду (в целом получился период 3 недели экспозиции), после чего также были отобраны 4 животных для анализа;

Затем следовал период восстановления (3 и 4 этапы):

- на третьем этапе животные пили водопроводную воду 2 недели, отобраны 4 животных;

- на четвёртом этапе - ещё 2 недели чистой воды, т. е. в сумме восстановительный период составил 4 недели, также отобрано 4 животных.

Дозы сурьмы и мышьяка, воздействующие на организм экспериментальных животных при пероральном поступлении, составили: сурьмы - 42-61 мкг/кг/сут, мышьяка - 10,0-15,0 мкг/кг/сут.

Содержание и использование лабораторных животных осуществлялось в соответствии с правилами, принятыми в ФГБОУ ВО «Новосибирский государственный медицинский университет» Минздрава РФ. Экспериментальные животные содержались группами по 8 голов в клетке, установленных на специальных стандартных стеллажах, с ежедневным контролем объёма выпитой воды из поилок.

Отбор образцов органов и тканей проводили после вскрытия предварительно наркотизированных крыс внутрибрюшинным введением нембутала в дозе 4 мг/100 г массы тела. Сбор мочи проводили с помощью обменных клеток в которые животных помещали с утра на 4-4,5 часа. Для определения элементного состава тканей были отобраны образцы печени, почек, сердца, легкого, бедренной мышцы, щитовидной железы, цельной крови, мочи и кала. Непосредственно после препарирования каждый из отобранных образцов взвешивался на лабораторных весах с фиксацией сырого веса и затем образцы высушивались при комнатной температуре до постоянного веса.

Для анализа были взяты навески 30 мг сухого вещества тканей, и на лабораторном прессе изготовле- ны таблетки. Анализ осуществлялся методом РФАСИ (рентгено-флуоресцентный анализ с использованием синхротронного излучения). Анализ проводился согласно инструкциям [24] и методом РФА-СИ [25] на станции элементного анализа VEPP-3 (ИЯФ СО РАН). При расчете концентраций использовался метод внешних стандартов. Обработка эмиссионных спектров производилась с помощью программы AXIL. Для образцов тканей использовались стандартные образцы SRM 1566a - Oyster Tissue, SRM 1577 Bovine Liver [26], A-13 - Animal Blood.

Расчёт индексов опасности содержания химических элементов в подземных водах и питьевой воде пос. Комсомольский производили в соответствии с [27] по формуле (1):

$$
H I=\operatorname{sum} H Q_{i},
$$

где $H I$ - индекс опасности действия нескольких веществ, $H Q=A D / R f D$; где $H Q$ - коэффициент опасности действия вещества; $A D$ - среднесуточная доза элемента, поступающего с перорально с водой, мг/кг/сут; RfD - референтная (безопасная) доза перорального поступления, мг/кг/сут.

Для обоснования маркёров экспозиции и ответа рассчитывали средние значения показателя в группе $(M)$, величину стандартной ошибки средней $( \pm \mathrm{m})$, достоверность различия средних $p \leq 0,05$.

Анализ токсикокинетики сурьмы и мышьяка проводили по параметрам [28]:

- константы скорости абсорбции $(\mathrm{Ka})$, элиминации $(\mathrm{Kel})$ :

$$
\frac{d C}{d t} / C t=-K a, e l,
$$

где $d C$ - разность концентрации элемента до и после затравки, а также после затравки и на момент периода восстановления; $d t$ - продолжительность затравки (21 сутки) или периода восстановления (28 суток); $C t$ - концентрация элемента на рассматриваемый период времени.

- $\quad$ клиренса (скорости элиминации), $\mathrm{Cl}$ :

$$
C l=K a, e l^{*} V d,
$$

где $V d$ - объёмная доза; $V d=D / C_{0}$, где $D$ - доза введённого вещества, мг/кг; $C_{0}-$ исходная концентрация вещества в ткани.

- периода полувыведения (t1/2) - время уменьшения (увеличения) концентрации вдвое:

$$
t 1 / 2=\ln 2 / K_{\text {, el }}={ }^{0,693} / \text { Ka, el }
$$

где 2 - двухкратное (увеличение) снижение концентрации; Ka,el - константа скорости абсорбции, элиминации.

Минеральный обмен в организме - строго регулируемый механизм, где все звенья взаимосвязаны $[28,29,30]$. Поэтому поступление в организм дополнительного вещества, тем более токсичного, вносит изменение прежде всего в механизмы регуляции [31-34]. Одним из наиболее наглядных выражений состояния регуляторных систем служит характеристика связи между различными элементами. В связи с 
этим, для анализа влияния мышьяка и сурьмы на организм крыс нами была исследована корреляция между содержанием мышьяка и других элементов в тканях органов экспериментальных животных в зависимости от периода проведения эксперимента (до затравки, во время затравки и после затравки).

Статистическую обработку результатов исследования проводили с помощью прикладных программ MS Excel.

\section{Результаты исследования}

\section{Состав воды}

Вода из гидроотвала Комсомольского хвостохранилища, которой поились животные на первых двух этапах эксперимента, содержит значительно повышенные, по сравнению с кларковыми значениями, концентрации элементов: S (в виде сульфат-иона вследствие окисления сульфидных минералов, содержащихся в отходах), $\mathrm{Ca}, \mathrm{Fe}, \mathrm{Mn}, \mathrm{Ni}, \mathrm{Cu}, \mathrm{Sr}$ (табл. 1). Наибольшее превышение над кларками определено для мышьяка и сурьмы, поступающих в воду гидроотвала из вещества отходов. Концентрации этих двух элементов и железа превышают ПДКхпн вод (раз): 1,16 (Fe), 170 (Sb), 21 (As). Расположение хвостохранилища в черте посёлка в непосредственной близости от жилой зоны и наличие природного разлома под его дренажной системой определили миграцию техногенных растворов в горизонты грунтовых вод. Вследствие этого в питьевых водах двух скважин было обнаружено повышенное содержание мышьяка (табл. 1): в скважине по ул. К. Маркса почти 10-кратное превышение ПДКхпн, в скважине по ул. Восточная содержание мышьяка приближалось к ПДКхпн.

Для гигиенической оценки уровня загрязнения воды гидроотвала и питьевых водозаборов была использована методология оценки риска с расчётами коэффициентов опасности по каждому элементу, установлением критических органов и систем организма на которые могут воздействовать исследуемые элементы и оценки индекса опасности суммарного воздействия разных элементов по критическим органам и системам организма.

По степени опасности для здоровья населения анализ коэффициентов опасности отдельных элементов и суммарного индекса опасности действия нескольких элементов на отдельные органы и системы организма показал, что превышение допустимого значения коэффициента опасности отмечается только для сурьмы и мышьяка (табл. 2). Суммарный индекс опасности воздействия на организм сурьмы и мышьяка вод гидроотвала превышает допустимый уровень более, чем в 20-60 раз для различных систем организма.

Таблица 1. Концентрации (C) и коэффициенты опасности (HQ) химических элементов в воде гидроотвала хвостохранилища и подземных водах пос. Комсомольский

Table 1. Concentrations $(C)$ and hazard factors $(H Q)$ of chemical elements in the water of the tailings dump and underground waters of Komsomolsky village

\begin{tabular}{|c|c|c|c|c|c|c|c|c|c|c|c|}
\hline \multirow[t]{2}{*}{ 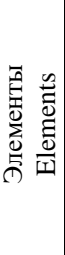 } & \multirow[t]{2}{*}{ 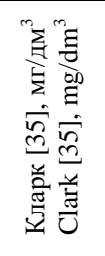 } & \multirow[t]{2}{*}{ 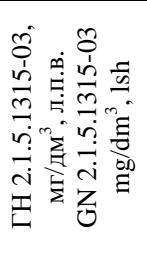 } & \multirow[t]{2}{*}{ 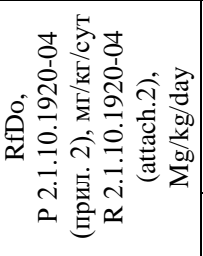 } & \multicolumn{2}{|c|}{$\begin{array}{l}\text { Питьевая вода } \\
\text { Drinking water }\end{array}$} & \multicolumn{2}{|c|}{$\begin{array}{c}\text { Гидроотвал } \\
\text { Hydraulic dump }\end{array}$} & \multicolumn{2}{|c|}{$\begin{array}{c}\text { Скважина по } \\
\text { ул. К. Маркса (выве- } \\
\text { дена из эксплуатации) } \\
\text { Well on the } \\
\text { K. Marks street } \\
\text { (decommissioned) }\end{array}$} & \multicolumn{2}{|c|}{$\begin{array}{c}\text { Скважина по ул. } \\
\text { Восточная } \\
\text { Well on the Vos- } \\
\text { tochnaya street }\end{array}$} \\
\hline & & & & $\begin{array}{l}\mathrm{C}, \mathrm{мг} / \text { дм }^{3} \\
\mathrm{C}, \mathrm{mg} / \mathrm{dm}^{3}\end{array}$ & HQ & $\begin{array}{l}\mathrm{C}, \mathrm{мг} / \text { дм }^{3} \\
\mathrm{C}, \mathrm{mg} / \mathrm{dm}^{3}\end{array}$ & HQ & $\begin{array}{c}\mathrm{C}, \mathrm{M \Gamma} / \mathrm{дm}^{3} \\
\mathrm{C}, \mathrm{mg} / \mathrm{dm}^{3}\end{array}$ & HQ & $\begin{array}{l}\mathrm{C}, \mathrm{мг} / \text { дм }^{3} \\
\mathrm{C}, \mathrm{mg} / \mathrm{dm}^{3}\end{array}$ & HQ \\
\hline $\mathrm{S}$ & 3,7 & - & - & 5,8 & - & 97 & - & 9,3 & - & 7,6 & - \\
\hline $\mathrm{Cl}$ & 7,8 & $350 *$ орг & - & 12 & - & 5,8 & - & 28 & - & 12 & - \\
\hline $\mathrm{K}$ & 2,3 & $20 * *$ физ & - & 2,3 & - & 3,1 & - & 1,4 & - & 1,5 & - \\
\hline $\mathrm{Ca}$ & 15 & $130 * *$ физ & 41,4 & 15 & 0,010 & 86 & 0,059 & 66 & 0,046 & 79 & 0,055 \\
\hline $\mathrm{Ti}$ & 0,003 & 0,1 общ. & 4,0 & 0,002 & 0,000014 & 0,0053 & 0,00001 & 0,0042 & 0,00001 & 0,002 & 0,00001 \\
\hline $\mathrm{Cr}$ & 0,001 & 0,05 с.т. & 0,005 & $<0,001$ & 0,0028 & 0,0012 & 0,007 & 0,0011 & 0,006 & 0,0004 & 0,002 \\
\hline $\mathrm{Mn}$ & 0,007 & 0,1 орг.окр. & 0,14 & 0,0068 & 0,0013 & 0,02 & 0,004 & $<0,0002$ & 0,00003 & 0,0015 & 0,0003 \\
\hline $\mathrm{Fe}$ & 0,04 & 0,3 орг.окр. & 0,3 & 0,1 & 0,0095 & 0,35 & 0,033 & 0,36 & 0,034 & 0,62 & 0,059 \\
\hline $\mathrm{Ni}$ & 0,0003 & 0,02 с.т. & 0,02 & $<0,001$ & 0,00071 & 0,012 & 0,017 & 0,006 & 0,009 & 0,0011 & 0,002 \\
\hline $\mathrm{Cu}$ & 0,007 & 1,0 с.т. & 0,019 & 0,01 & 0,015 & 0,07 & 0,105 & $<0,002$ & 0,002 & $<0,002$ & 0,002 \\
\hline $\mathrm{Zn}$ & 0,02 & 1,0 общ. & 0,3 & 0,03 & 0,0028 & 0,042 & 0,004 & 0,0031 & 0,0003 & 0,0020 & 0,0002 \\
\hline $\mathrm{Rb}$ & 0,001 & 0,1 с.т. & - & $<0,001$ & - & 0,0021 & - & 0,004 & - & 0,002 & - \\
\hline $\mathrm{Sr}$ & 0,07 & 7,0 с.т. & 0,6 & 0,3 & 0,014 & 0,31 & 0,015 & 0,25 & 0,012 & 0,25 & 0,012 \\
\hline Mo & 0,0006 & 0,07 с.т. & 0,005 & $<0,001$ & 0,0028 & 0,0016 & 0,009 & 0,0009 & 0,005 & 0,001 & 0,006 \\
\hline As & 0,002 & 0,01 с.т. & 0,0003 & $<0,001$ & 0,047 & 0,21 & 20,0 & 0,089 & 8,4 & 0,0083 & 0,79 \\
\hline $\mathrm{Pb}$ & 0,001 & 0,01 с.т. & 0,0035 & $<0,001$ & 0,0040 & 0,001 & 0,008 & 0,00075 & 0,006 & $<0,0002$ & 0,001 \\
\hline $\mathrm{Sb}$ & 0,00007 & 0,005 с.т. & 0,0004 & $<0,008$ & 0,28 & 0,85 & 60,7 & 0,00028 & 0,020 & 0,00025 & 0,018 \\
\hline
\end{tabular}

Примечание: *-по п. 3.4.1. (табл. 2) СанПиН 2.1.4.1074-01. Гигиенические требования к качеству водь иентрализованных систем питьевого водоснабжения. Контроль качества. Гигиенические требования к обеспечению безопасности систем горячего водоснабжения. Санитарно-эпидемиологические правила и нормативы; ** - по п. 4.7. (табл. 5) СанПиН 2.1.4.1116-02. Питьевая вода. Гигиенические требования к качеству воды, расфасованной в емкости. Контроль качества.

Note: *-paragraph 3.4.1. (Table 2) SanPiN 2.1.4.1074-01. Hygienic requirements for water quality of centralized drinking water supply systems. Quality control. Hygienic requirements for ensuring the safety of hot water systems. Sanitary and epidemiological rules and regulations; **-according to the paragraph 4.7. (Table 5) SanPiN 2.1.4.1116-02. Drinking water. Hygienic requirements for the quality of water packaged in containers. Quality control. 
Таблица 2. Индексы опасности суммарного действия нескольких веществ (НI) для критических органов и систем организма сточных вод в питьевой воде (1), гидроотвала (2), подземных вод из скважин по ул. К.Маркса (3) и Восточная (4)

Table 2. Danger indices of the total action of several substances (HI) for critical organs and body systems of wastewater in drinking water (1), hydraulic dump (2), underground water from wells of $K$. Marks street (3) and Vostochnaya street (4)

\begin{tabular}{|c|c|c|c|c|}
\hline $\begin{array}{c}\text { Критические органы и системы } \\
\text { opганизма } \\
\text { Critical organs and systems } \\
\text { of the body }\end{array}$ & 1 & 2 & 3 & 4 \\
\hline Печень/Liver & 0,019 & 0,13 & 0,02 & 0,01 \\
\hline Почки/Kidneys & 0,016 & 0,08 & 0,06 & 0,06 \\
\hline \begin{tabular}{|l} 
Гормональная система \\
Hormonal system
\end{tabular} & 0,052 & 20,01 & 8,48 & 0,79 \\
\hline $\begin{array}{l}\text { Биохимические показатели крови } \\
\text { (сахар, холестерин) } \\
\text { Biochemical blood parameters } \\
\text { (sugar, cholesterol) }\end{array}$ & 0,30 & 60,79 & 0,07 & 0,07 \\
\hline $\begin{array}{l}\text { Желудочно-кишечный } \\
\text { тракт/Gastrointestinal tract }\end{array}$ & 0,066 & 20,13 & 8,49 & 0,80 \\
\hline $\begin{array}{l}\text { Центральная нервная система } \\
\text { Central nervous system }\end{array}$ & 0,053 & 20,01 & 8,48 & 0,79 \\
\hline Система крови/Blood system & 0,019 & 0,07 & 0,05 & 0,06 \\
\hline $\begin{array}{l}\text { Иммунная система } \\
\text { Immune system }\end{array}$ & 0,057 & 20,03 & 8,51 & 0,85 \\
\hline $\begin{array}{l}\text { Сердечнососудистая } \\
\text { система/Cardiovascular system }\end{array}$ & 0,048 & 20,02 & 8,48 & 0,79 \\
\hline Костная система/Bone system & 0,014 & 0,01 & 0,01 & 0,01 \\
\hline $\begin{array}{l}\text { Периферическая нервная система } \\
\text { Peripheral nervous system } \\
\end{array}$ & 0,052 & 20,01 & 8,48 & 0,79 \\
\hline Развитие/Evolution & 0,0041 & 0,01 & 0,01 & 0,00 \\
\hline Кожа/Skin & 0,057 & 20,03 & 8,51 & 0,85 \\
\hline Слизистые/Mucous & 0,012 & 0,04 & 0,04 & 0,06 \\
\hline $\begin{array}{l}\text { Репродуктивная система } \\
\text { Reproductive system }\end{array}$ & 0,0041 & 0,01 & 0,01 & 0,00 \\
\hline
\end{tabular}

В подземной воде из скважины по улице К. Маркса содержание химических элементов, кроме мышьяка, соответствовало гигиеническим нормативам, а концентрация мышьяка превышала предельно допу-
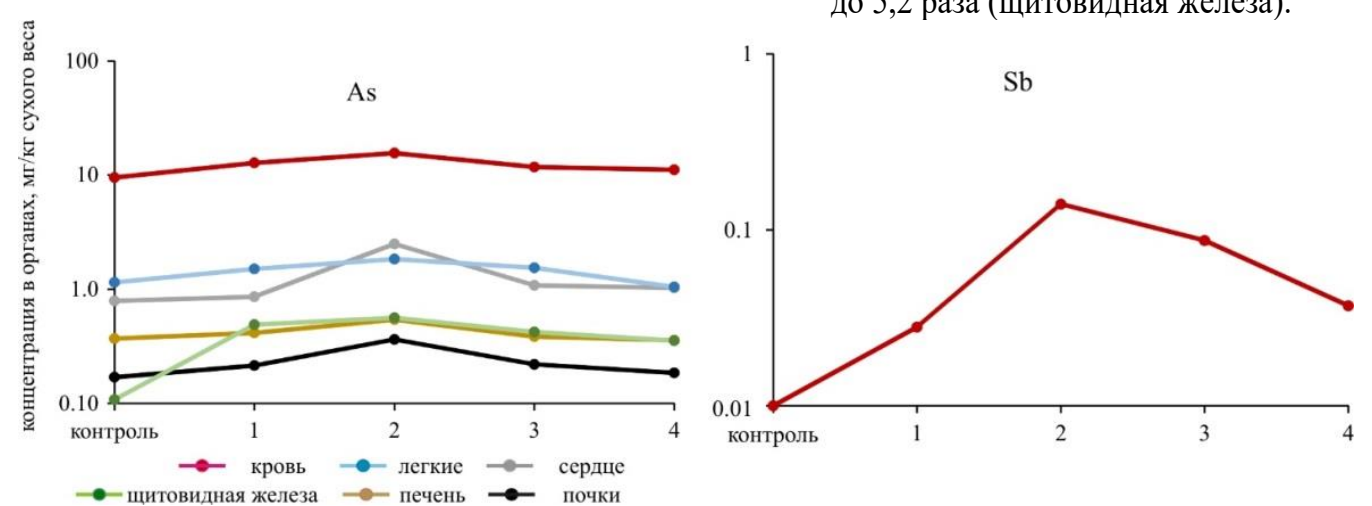

Рис. 2. Изменение содержания мышьяка в тканях органов и сурьмы в крови крыс самияов линии Вистар в эксперименте: 1 - после 1 недели перорального поступления As u Sb; 2-nосле 3-х недель; 3 - после 2-х недель восстановительного периода; 4 - после 4-х недельного периода восстановления

Fig. 2. Change in arsenic content in the tissues of organs and antimony in the blood of rats of males of the Wistar strain in the experiment: 1 -after 1 week of oral intake of As and Sb; 2 -after 3 weeks; 3 -after 2 weeks of the recovery period; 4-after a 4-week recovery period стимую в 8,9 раза. Органами и системами организма, для которых суммарный индекс опасности хронического перорального воздействия нескольких химических элементов подземных вод (НI) из скважины по ул. К. Маркса превышает допустимый уровень $(1,0)$, являются - гормональная $(8,48)$, желудочнокишечный тракт $(8,49)$, центральная нервная система $(8,48)$, иммунная система $(8,51)$, сердечно-сосудистая система $(8,48)$, нервная система $(8,48)$, кожа $(8,51)$.

В подземной воде из скважины по ул. Восточная содержание химических элементов не превышает гигиенических нормативов, а суммарный индекс опасности хронического перорального воздействия нескольких химических элементов для критических органов и систем не превышает допустимый уровень $(1,0)$.

Принимая во внимание, что воды гидроотвала содержат большие концентрации сурьмы и мышьяка и в результате поступления дренажных вод с мест складирования отходов происходит загрязнение подземных вод мышьяком, для проведения санитарнотоксикологического эксперимента были выбраны стоки гидроотвала, как содержащие сурьму и мышьяк в повышенных концентрациях.

Изменения концентраций мышьяка и сурьмы в тканях органов

Уровни испытанных доз перорального поступления в организм лабораторных животных составили: 42-62 мкг/кг/сут сурьмы и 10-15 мкг/кг/сут мышьяка. Продолжительность затравки - 3 недели (21 день).

Результаты эксперимента показали, что содержание мышьяка во всех исследованных органах возрастали после 1 недели запаивания животных водой из гидроотвала, и ещё более - после 3-х недель (рис. 2). В наибольшей степени мышьяк накапливался в почках, сердце и щитовидной железе. Причём если в почках и сердце на первом этапе шло сравнительно небольшое накопление (содержание мышьяка увеличилось в $1,3(29 \%)$ и $1,1(8,9 \%)$ раза по сравнению с контролем, соответственно), то в щитовидной железе за это же время концентрация мышьяка возросла в 4,5 раза $(340 \%)$. На втором этапе эксперимента содержание мышьяка увеличилось от 1,5 раз (печень) до 5,2 раза (щитовидная железа). 
Было отмечено и более высокое содержание мышьяка в моче опытной группы животных по сравнению с контролем (на 27 \%), тогда как в кале, наоборот, у животных опытной группы содержание мышьяка было снижено по сравнению с контролем на $31 \%$. Таким образом, в результате питьевой нагрузки мышьяком в дозах на уровне 10-15 мг/кг/сут, по-видимому, в организме активизируются процессы его более активного поглощения из пищеварительного тракта.

Содержание сурьмы было определено только в крови (во всех остальных органах её содержание было ниже предела обнаружения), и установлено превышение над уровнем контроля в 2,8 раза на первом и в 14 раз на втором этапе. Следовательно, полученные данные показывают, что сурьма, как и мышьяк, хорошо усваивается организмом из пищеварительного тракта и поступает в кровь в значительных количествах.

В восстановительный период (3-й и 4-й этапы эксперимента) определено снижение концентраций мышьяка во всех органах. В печени, почках и легких содержание этого элемента в конце эксперимента (4 недели запаивания чистой водой) достигло контрольного уровня, а в щитовидной железе и крови осталось повышенным. Концентрация сурьмы в крови заметно снизилась, но осталась более чем в 3 раза выше контрольной.

\section{Элементный состав тканей}

Пероральное поступление воды гидроотвала в течение 3-х недель привело к существенным изменениям элементного состава тканей внутренних органов экспериментальных животных. Повышенные концентрации ряда элементов в воде гидроотвала привели к их накоплению в некоторых органах, а биохимические реакции в организмах животных и действие защитных механизмов выразились в неоднозначных тенденциях распределения элементов в тканях.

Как показали результаты анализа коэффициентов опасности элементов сточных вод гидроотвала, их вредное действие на организм при пероральном поступлении связано с повышенными концентрациями только мышьяка и сурьмы, концентрации которых в тканях органов экспериментальных животных увеличивались. Но пероральное воздействие повышенных концентраций мышь- яка и сурьмы сопровождалось не только увеличением концентрации в тканях органов этих элементов, но и изменением содержания других элементов.

По направленности этих изменений органы разделились на три группы:

1) печень и почки: увеличение содержания элементов $\mathrm{S}, \mathrm{Ca}, \mathrm{Ti}, \mathrm{Mn}, \mathrm{Ni}$ после 3-х недель запаивания водой из гидроотвала и их снижение в восстановительный период (после 4-х недель чистой воды), рис. 3. Видимо, помимо накопления элементов, содержащихся в повышенных концентрациях в воде, в печени и почках, происходила активация процессов детоксикации, а затем поступление в организмы животных чистой воды способствовало удалению лишних примесей.

2) кровь и щиттовидная железа: в крови шло снижение концентраций $\mathrm{S}, \mathrm{Cr}, \mathrm{Fe}, \mathrm{Br}$ в течение всего эксперимента, как в главном депо, передающем часть элементов в процессы детоксикации; в то же время для элементов $\mathrm{Ti}, \mathrm{Mn}, \mathrm{Cu}, \mathrm{Zn}$, Мо после снижения содержания на 2-м этапе во время восстановительного периода (4-й этап) определено повышение концентраций (рис. 4); из щитовидной железы выносились S, Ca, Ti, Cr, Mn, Ni, Cu, Mo c увеличением на 4-м этапе содержания $\mathrm{Ca}, \mathrm{Mn}, \mathrm{Cu}$. Повышение концентрации элементов в крови, щитовидной железе в восстановительном периоде после их снижения при интоксикации сурьмой и мышьяком свидетельствует о влиянии сурьмы и мышьяка на окислительно-восстановительные процессы, в которых эти элементы принимают участие.

3) сердие, легкие, мышщцы (органы мишени и адаптации): в этих органах происходило накопление одних элементов и снижение концентраций других; в сердце на втором этапе увеличились концентрации $\mathrm{S}$ и $\mathrm{Br}$ с последующим снижением, но уменьшились $\mathrm{Cr}, \mathrm{Mn}, \mathrm{Fe}, \mathrm{Ni}, \mathrm{Cu}$ (рис. 5). В легких вначале увеличивались, а затем снижались концентрации $\mathrm{S}, \mathrm{Ca}, \mathrm{Ti}$, а элементы $\mathrm{Cr}, \mathrm{Mn}, \mathrm{Fe}, \mathrm{Ni}, \mathrm{Cu}, \mathrm{Zn}$, Мо выносились по ходу эксперимента. В мышцах возросли концентрации $\mathrm{S}, \mathrm{Ca}, \mathrm{Ti}, \mathrm{Cr}$, но снизились $\mathrm{Fe}, \mathrm{Ni}, \mathrm{Cu}$.

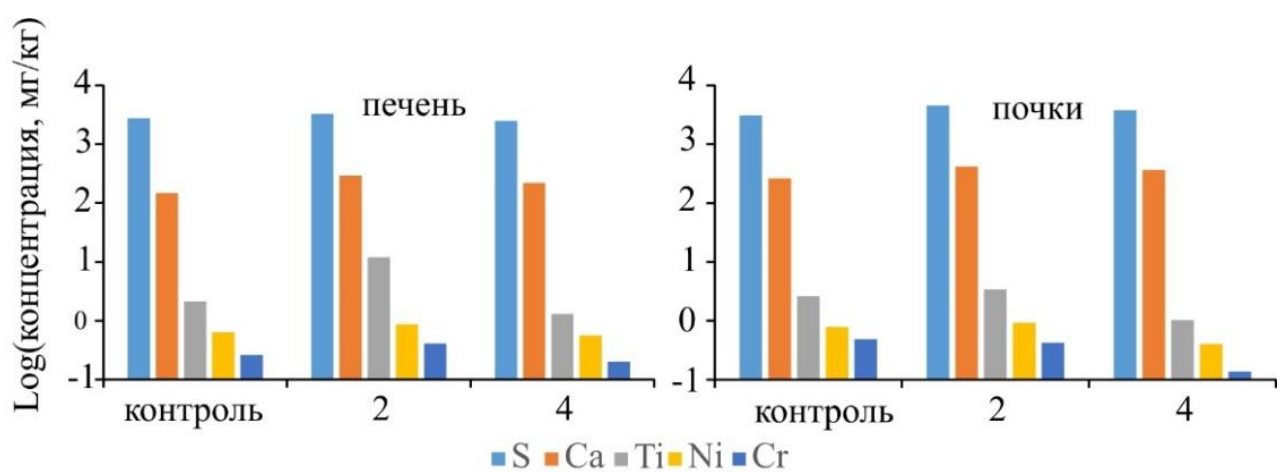

Pис. 3. Изменение конщентраций элементов в тканях печени и почек в эксперименте: здесь и далее 2 - после 2-го этапа, 4-после 4-го этапа

Fig. 3. Changes in concentrations of elements in the tissues of the liver and kidneys in the experiment: hereinafter, 2 - after the $2^{\text {nd }}$ stage, 4 - after the $4^{\text {th }}$ stage 


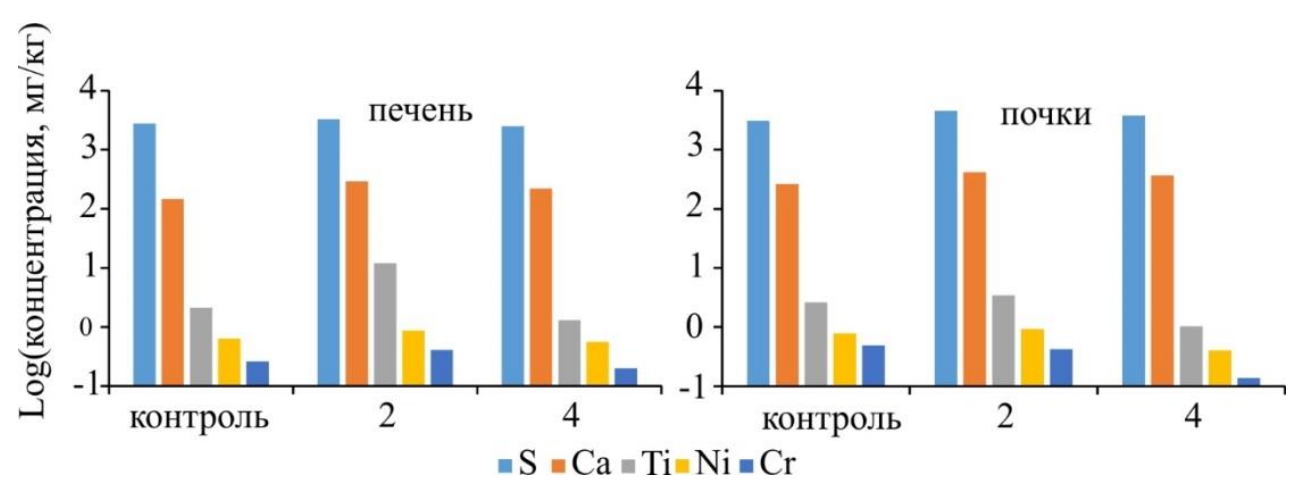

Pис. 4. Изменение концентраций элементов в крови и щитовидной железе в эксперименте

Fig. 4. Change in concentrations of elements in blood and thyroid in the experiment
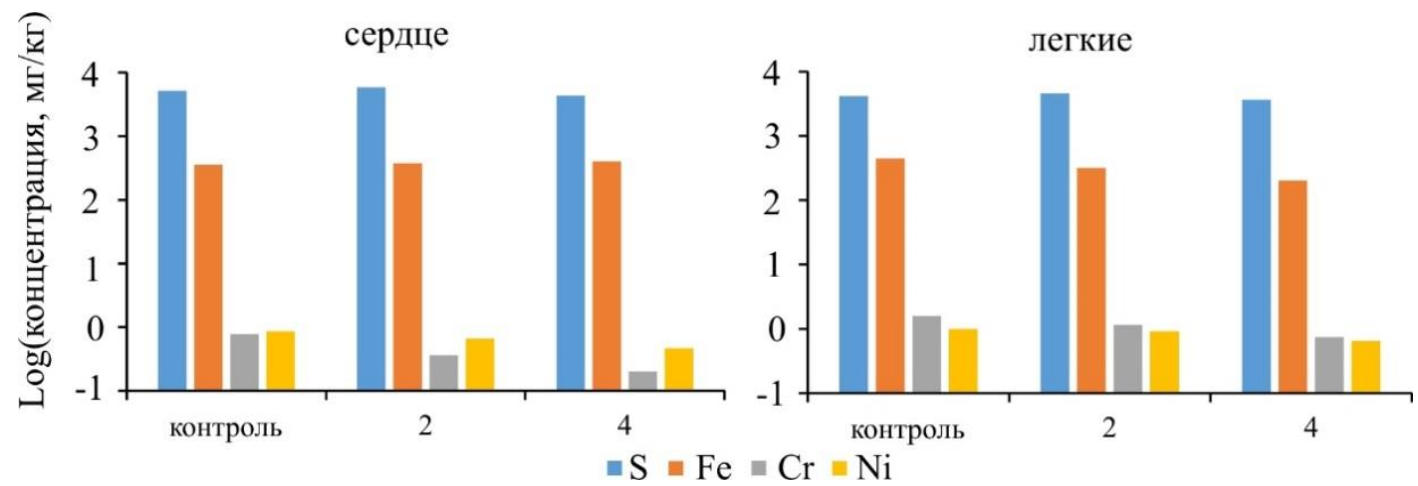

Pис. 5. Изменение кониентраций элементов в тканях сердия и легких в эксперименте

Fig. 5. Change in concentrations of elements in the tissues of the heart and lungs in the experiment

\section{Перераспределение элементов}

Элементы, судя по направленности изменения их концентрации в тканях органов, активно перераспределялись в ходе эксперимента.

Сера - её содержание увеличивалось при запаивании водой гидроотвала в печени, почках, сердце, легких и мышцах, причём наиболее всего в почках - на $47 \%$, в то время как в остальных органах накопление не превышало 19 \%. Мышьяк и сурьма по основному механизму токсического действия являются «тиоловыми ядами», взаимодействуя с SH-группами, выводят серу из биологических молекул в виде сульфатов, удаляемых через почки с мочой. Поэтому сера - показатель анаболических, синтетических процессов в составе белков и аминокислот, но и катаболических, в виде сульфатов. В восстановительный период шло вымывание серы до уровня ниже контрольного, но в почках концентрация осталась выше. При этом в крови и щитовидной железе концентрации серы снижались (на 11 и $39 \%$, соответственно), несмотря на высокое содержание этого элемента в воде, а в период восстановления происходило последующее снижение в результате чего в конце эксперимента содержание серы в крови и щитовидной железе составляло на 38 и $41 \%$ ниже контроля, что, по-видимому, можно отнести к потерям серы инактивированных SH-групп. Продолжение снижения содержания серы в восстановительном периоде, по-видимому, свидетельствует о тяжести поражения органа и недостаточности времени на восстановление, учитывая иммунотоксичность сурьмы и мышьяка [29]. Близкая тенденция наблюда- лась для кальция и титана, за исключением того, что эти элементы снижают концентрации в сердце в период затравки, и ещё более - в восстановительный, при том, что в крови на протяжении всего эксперимента увеличивалась концентрация кальция. Калий и кальций в значительной мере регулируются гормональной системой и поэтому могут служить показателями стресса. Возрастание кальция в крови согласуется с состоянием стресса, тогда как снижение его концентрации в сердце, возможно, является особенностью его биохимической регуляции.

Элементы, концентрации которых возрастали в течение всего эксперимента (в 1-й и 2-й периоды затравки и далее - в восстановительный период), - это калий (во всех органах), цинк (в печени, почках, сердце и мышцах), селен (в почках, сердце, мышцах и щитовидной железе), бром и рубидий (во всех органах, кроме крови).

Для железа, марганца, хрома, меди, никеля, молибдена процессы выноса преобладали над накоплением в большинстве органов. При этом железо, вымываясь из печени, легких, мышц и крови, концентрировалось в сердце и щитовидной железе. Содержание марганца возрастало в период затравки и снижалось в восстановительный период в почках и печени, во всех других органах шло постепенное снижение его концентраций.

Выявленные различия содержания элементов в тканях органов экспериментальных животных указывают на очевидную реакцию стресса в силу повышения содержания в тканях органов и крови элементов, 
задействованных в механизмах гормональной регуляции гомеостаза - кальций, хлор, калий. В то же время снижение концентрации в органах и увеличение в моче - хрома, железа, марганца, свидетельствуют о реализации механизма их замещения сурьмой и мышьяком в ферментных системах организма.

По истечении 2-х недель восстановительного периода различия в элементном составе тканей органов по сравнению с периодом затравки заключались:

- в снижении уровня содержания кальция, стронция с повышенного на пониженный в тканях щитовидной железы соответственно (на 15-39, 81 \%) при сохранении повышенного уровня стронция только в тканях сердца (на $22 \%$ );

- снижении уровня содержания хрома (на 19-52 \%), молибдена (на 48 \%), никеля (на 20-51\%)

- нормализации содержания хлоридов, кроме тканей лёгкого и щитовидной железы, где повышенный уровень сохранялся (на 27-38 \%);

- увеличении уровня калия (на 28-56 \%), рубидия (на 19-21\%) почти во всех исследованных органах;

- колебании уровня содержания железа от пониженного на 30 \% в тканях мышц до повышенного в тканях щитовидной железы на $22 \%$.

В целом в конце эксперимента, по истечении 4-х недель восстановительного периода, была отмечена нормализация содержания хрома в тканях органов за исключением крови, где дефицит хрома по сравнению с контролем составил 27 \%. Но при этом сохранялся повышенный уровень калия в тканях всех исследованных органов, что соответствовало сохраняющемуся повышенному уровню мышьяка в тканях сердца (на 30 \%). Отличительной особенностью элементного состава тканей органов в этот период наблюдения стало системное снижение уровня содержания титана в печени, почках, легких, мышцах, щитовидной железе, крови на 25-50 \%. В моче, как и после 2-х недель восстановительного периода, было отмечено повышенное выведение из организма меди, железа, калия, марганца, никеля, свинца и пониженное выведение хрома, концентрация которого в тканях щитовидной железы превышала уровень контроля на $23 \%$.

Расчёты параметров токсикокинетики мышьяка и сурьмы во внутренних органах самцов белых крыс линии Вистар (табл. 3) при пероральном поступлении показали, что их абсорбция тканями внутренних органов происходит с меньшей скоростью, чем выведение (константы абсорбции меньше, чем константы элиминации, а период полунакопления продолжительнее периода полувыведения). Наиболее высокая скорость абсорбции мышьяка в щитовидной железе и сердце (период полунакопления 18 и 23 суток, период полувыведения, соответственно 12 и 14 суток). Наименее интенсивны обменные процессы мышьяка наблюдались в тканях мышц и лёгкого. В мышце период полунакопления составляет 58 суток, а полувыведения - 49 суток. В тканях лёгкого, соответственно, -49 и 26 суток.
Таблица 3. Параметры токсикокинетики мышьяка и сурьмы при подостром пероральной затравке самиов бельх крыс линии Вистар

Table 3. Parameters of toxicokinetics of arsenic and antimony in subacute oral inoculation of male Wistar white rats

\begin{tabular}{|c|c|c|c|c|c|}
\hline $\begin{array}{l}\text { Элемент } \\
\text { Element }\end{array}$ & $\begin{array}{l}\text { Орган } \\
\text { Organ }\end{array}$ & $\begin{array}{c}\text { Вид } \\
\text { кинетики } \\
\text { Kinetics } \\
\end{array}$ & $\mathrm{KE}$ & $\mathrm{Cl}$ & $\begin{array}{l}\mathrm{t} 1 / 2, \\
\text { сут }\end{array}$ \\
\hline \multirow{16}{*}{ As } & \multirow{2}{*}{$\begin{array}{l}\text { Печень } \\
\text { Liver }\end{array}$} & $\begin{array}{l}\text { Абсорбция } \\
\text { Absorption }\end{array}$ & $\begin{array}{c}0,01 \\
4 \\
\end{array}$ & 0,56 & 49 \\
\hline & & $\begin{array}{c}\text { Элиминация } \\
\text { Elimination }\end{array}$ & $\begin{array}{c}0,01 \\
8\end{array}$ & 0,50 & 39 \\
\hline & \multirow{2}{*}{$\begin{array}{l}\text { Почки } \\
\text { Kidneys }\end{array}$} & $\begin{array}{c}\text { Абсорбция } \\
\text { Absorption }\end{array}$ & $\begin{array}{c}0,02 \\
4\end{array}$ & 2,00 & 29 \\
\hline & & $\begin{array}{l}\text { Элиминация } \\
\text { Elimination }\end{array}$ & $\begin{array}{c}0,03 \\
2\end{array}$ & 1,33 & 22 \\
\hline & \multirow{2}{*}{$\begin{array}{c}\text { Сердце } \\
\text { Heart }\end{array}$} & $\begin{array}{l}\text { Абсорбция } \\
\text { Absorption }\end{array}$ & $\begin{array}{c}0,03 \\
1\end{array}$ & 0,52 & 23 \\
\hline & & $\begin{array}{l}\text { Элиминация } \\
\text { Elimination }\end{array}$ & $\begin{array}{c}0,05 \\
1\end{array}$ & 0,31 & 14 \\
\hline & \multirow{2}{*}{$\begin{array}{l}\text { Лёгкое } \\
\text { Lung }\end{array}$} & $\begin{array}{l}\text { Абсорбция } \\
\text { Absorption }\end{array}$ & $\begin{array}{c}0,01 \\
4\end{array}$ & 0,17 & 49 \\
\hline & & $\begin{array}{l}\text { Элиминация } \\
\text { Elimination }\end{array}$ & $\begin{array}{c}0,02 \\
7\end{array}$ & 0,22 & 26 \\
\hline & \multirow{2}{*}{$\begin{array}{l}\text { Мышцы } \\
\text { Muscle }\end{array}$} & $\begin{array}{c}\text { Абсорбция } \\
\text { Absorption }\end{array}$ & $\begin{array}{c}0,01 \\
2 \\
\end{array}$ & 0,86 & 58 \\
\hline & & $\begin{array}{l}\text { Элиминация } \\
\text { Elimination }\end{array}$ & $\begin{array}{c}0,01 \\
4 \\
\end{array}$ & 0,77 & 49 \\
\hline & \multirow{2}{*}{$\begin{array}{c}\text { Щитовидная } \\
\text { железа } \\
\text { Thyroid }\end{array}$} & $\begin{array}{c}\text { Абсорбция } \\
\text { Absorption }\end{array}$ & $\begin{array}{c}0,03 \\
8 \\
\end{array}$ & 5,25 & 18 \\
\hline & & $\begin{array}{l}\text { Элиминация } \\
\text { Elimination }\end{array}$ & $\begin{array}{c}0,06 \\
0\end{array}$ & 1,59 & 12 \\
\hline & \multirow{2}{*}{$\begin{array}{l}\text { Кровь } \\
\text { Blood }\end{array}$} & $\begin{array}{c}\text { Абсорбция } \\
\text { Absorption }\end{array}$ & $\begin{array}{c}0,01 \\
5 \\
\end{array}$ & 0,02 & 45 \\
\hline & & $\begin{array}{c}\text { Элиминация } \\
\text { Elimination }\end{array}$ & $\begin{array}{c}0,01 \\
5\end{array}$ & 0,01 & 48 \\
\hline & \multirow{2}{*}{$\begin{array}{l}\text { Моча } \\
\text { Urine }\end{array}$} & $\begin{array}{c}\text { Абсорбция } \\
\text { Absorption }\end{array}$ & $\begin{array}{c}0,02 \\
4 \\
\end{array}$ & 2,00 & 29 \\
\hline & & $\begin{array}{l}\text { Элиминация } \\
\text { Elimination }\end{array}$ & $\begin{array}{c}0,03 \\
2\end{array}$ & 1,33 & 22 \\
\hline \multirow{4}{*}{$\mathrm{Sb}$} & \multirow{2}{*}{$\begin{array}{l}\text { Кровь } \\
\text { Blood }\end{array}$} & $\begin{array}{l}\text { Абсорбция } \\
\text { Absorption }\end{array}$ & $\begin{array}{c}0,03 \\
2 \\
\end{array}$ & $\begin{array}{c}27,6 \\
6 \\
\end{array}$ & 22 \\
\hline & & $\begin{array}{c}\text { Элиминация } \\
\text { Elimination }\end{array}$ & $\begin{array}{c}0,05 \\
8 \\
\end{array}$ & $\begin{array}{c}16,5 \\
8 \\
\end{array}$ & 12 \\
\hline & \multirow{2}{*}{$\begin{array}{l}\text { Мышцы } \\
\text { Muscle }\end{array}$} & $\begin{array}{l}\text { Абсорбция } \\
\text { Absorption }\end{array}$ & $\begin{array}{c}0,01 \\
6 \\
\end{array}$ & 9,68 & 44 \\
\hline & & $\begin{array}{l}\text { Элиминация } \\
\text { Elimination }\end{array}$ & $\begin{array}{c}0,02 \\
4\end{array}$ & 9,52 & 29 \\
\hline
\end{tabular}

Установлено, что обмен сурьмы протекает в организме крыс с большей скоростью, чем обмен мышьяка. Так, константа скорости абсорбции сурьмы в крови $(0,032)$ превышает константу мышьяка $(0,015)$ более чем в два раза. А константа скорости элиминации сурьмы в крови $(0,058)$ превышает аналогичный параметр мышьяка $(0,015)$ почти в четыре раза. В мышечной ткани константа скорости абсорбции сурьмы $(0,016)$ также превышает константу скорости абсорбции мышьяка $(0,012)$, но в меньшей мере. Такая же закономерность отмечается для константы скорости элиминации сурьмы и мышьяка в мышечной ткани.

Соотношение величин поступления и выведения химического элемента в организме определяется в конечном итоге особенностью метаболических процессов, количеством субстрата для взаимодействия $[28,30,31]$. И если принять, что абсорбция в большей степени зависит от способности элемента проникать в 
ткань органа, то элиминация - это свойство ткани избавляться от продуктов метаболизма [32, 33]. В связи с этим были рассчитаны соотношения констант абсорбции и элиминации для мышьяка и сурьмы в тканях разных органов. Расчёты показали, что только константа абсорбции и элиминации мышьяка в крови близки друг к другу $(0,015)$. Во всех других случаях скорость абсорбции меньше скорости элиминации. И эта разница возрастает в ряду органов для мышьяка: кровь, печень, почки, моча, щитовидная железа, сердце, лёгкие; для сурьмы в ряду органов: мышцы, кровь.

Расчет коэффициентов линейной корреляции между содержанием мышьяка в тканях органов белых крыс линии Вистар до, во время и после перорального поступления мышьяка и сурьмы (табл. 4.) в дозах 0,015 и 0,061 мг/кг/сут показал, что в интактном организме белых крыс существует статистически достоверная связь содержания в тканях органов мышьяка с хлоридами $(\mathrm{r}=+0,66 ; \mathrm{p}<0,01)$, калием $(\mathrm{r}=0,71 ; \mathrm{p}<0,005)$, железом (r=0,97; $<00,0001)$, ртутью $(\mathrm{r}=0,61 ; \mathrm{p}<0,05)$.

Таблица 4. Коррелячия между содержанием мышьяка и отдельными элементами в тканях органов бельх крыс линии Вистар до и во время затравки мышьяком и сурьмой в дозах 0,015 и 0,061 мг/кг/сут соответственно и в период восстановления

Table 4. Correlation between the arsenic content and individual elements in the tissues of the organs of white rats of the Wistar line before and during seeding with arsenic and antimony at doses of 0,015 and 0,061 $\mathrm{mg} / \mathrm{kg} /$ day, respective$l y$, and during the recovery period

\begin{tabular}{|c|c|c|c|c|c|c|}
\hline $\begin{array}{c}\text { Время экспе- } \\
\text { римента } \\
\text { Experiment } \\
\text { time }\end{array}$ & $\begin{array}{c}\text { Статистиче- } \\
\text { ский пара- } \\
\text { метр } \\
\text { Statistical } \\
\text { parameter }\end{array}$ & $\mathrm{Cl}$ & $\mathrm{K}$ & $\mathrm{Fe}$ & $\mathrm{Hg}$ & $\mathrm{Sb}$ \\
\hline \multirow{3}{*}{$\begin{array}{c}\text { Фон } \\
\text { Background }\end{array}$} & $\mathrm{r}$ & 0,66 & 0,71 & 0,97 & 0,61 & H.O. \\
\hline & $\mathrm{t}$ & 2,87 & 3,56 & 34,79 & 2,39 & H.o. \\
\hline & $\mathrm{p}$ & 0,0075 & 0,0013 & 0,0000 & 0,023 & H.O. \\
\hline \multirow{3}{*}{$\begin{array}{c}1 \text { неделя } \\
\text { затравки } \\
1 \text { week of } \\
\text { inoculating }\end{array}$} & $\mathrm{r}$ & 0,65 & $-0,07$ & 0,75 & 0,38 & 0,75 \\
\hline & $\mathrm{t}$ & 2,71 & 0,18 & 4,30 & 1,07 & 4,24 \\
\hline & $\mathrm{p}$ & 0,011 & 0,89 & 0,0002 & 0,29 & 0,0002 \\
\hline \multirow{3}{*}{$\begin{array}{c}3 \text { недели } \\
\text { затравки } \\
3 \text { weeks of } \\
\text { inoculating }\end{array}$} & $\mathrm{r}$ & 0,52 & $-0,12$ & 0,87 & 0,39 & 0,72 \\
\hline & $\mathrm{t}$ & 1,77 & 0,31 & 8,70 & 1,14 & 3,69 \\
\hline & $\mathrm{p}$ & 0,087 & 0,74 & 0,0000 & 0,26 & 0,0009 \\
\hline \multicolumn{7}{|c|}{ Восстановительный период/Recovery period } \\
\hline \multirow{3}{*}{$\begin{array}{l}2 \text { недели } \\
2 \text { weeks }\end{array}$} & $\mathrm{r}$ & 0,39 & $-0,10$ & 0,79 & $-0,15$ & 0,21 \\
\hline & $\mathrm{t}$ & 1,11 & 0,25 & 5,13 & 0,38 & 0,53 \\
\hline & $\mathrm{p}$ & 0,27 & 0,82 & 0,00002 & 0,76 & 0,60 \\
\hline \multirow{3}{*}{$\begin{array}{l}4 \text { недели } \\
4 \text { weeks }\end{array}$} & $\mathrm{r}$ & 0,28 & $-0,04$ & 0,80 & 0,61 & H.o. \\
\hline & $\mathrm{t}$ & 0,74 & 0,11 & 5,36 & 2,39 & H.o. \\
\hline & $\mathrm{p}$ & 0,47 & 0,92 & 0,00001 & 0,024 & H.o. \\
\hline
\end{tabular}

Примечание: $r$ - коэффициент линейной парной корреляиии, $t$ - коэффиичент Стьюдента, $p$ - достоверность коэффициента коррелячии.

Note: $r$-coefficient of linear pair correlation, $t$-Student's coefficient, $p$-correlation coefficient reliability.

С началом затравки мышьяком и сурьмой (через 1 неделю) произошло изменение связей между со- держанием мышьяка и другими элементами. При сохранившихся связях мышьяка с хлоридами и железом потеряла статистическую достоверность зависимость между мышьяком и калием, мышьяком и ртутью и появилась связь между содержанием мышьяка и сурьмы. В период продолжения затравки связи между мышьяком и железом, мышьяком и сурьмой сохранялись, но исчезла связь между мышьяком и хлоридами. По истечении 2-х недель восстановительного периода было отмечено исчезновение связи между мышьяком и сурьмой, а по истечении 4-х недель восстановления вновь появилась связь между содержанием мышьяка и ртути, тогда как восстановления связей мышьяка с хлоридами и калием не произошло.

Анализ связи между содержанием мышьяка и других элементов в тканях различных органов белых крыс показал, что перечень элементов, с которыми мышьяк вступает во взаимодействие значительно расширился. Также отличительной чертой анализа в разрезе органов стало появление обратных связей (табл. 5).

В крови содержание мышьяка было прямо связано с содержанием сурьмы, что, несомненно, логично, так как сурьма поступала в организм вместе с мышьяком, эта зависимость лишь подтверждает актуальность перорального пути поступления сурьмы в теплокровный организм. Также с мышьяком в крови был связан молибден $(\mathrm{r}=0,682)$ и свинец $(\mathrm{r}=-0,81)$, но направленность связи была обратная, что свидетельствует о конкурентных отношениях этих элементов за субстрат взаимодействия.

В легочной ткани содержание мышьяка было связано с содержанием серы $(\mathrm{r}=0,70)$, молибдена $(\mathrm{r}=0,75)$, свинца $(\mathrm{r}=0,82)$. В бедренной мышце содержание мышьяка было связано с содержанием серы $(\mathrm{r}=0,82)$, титана $(\mathrm{r}=0,77)$, хрома $(\mathrm{r}=0,91)$, меди $(\mathrm{r}=-0,73)$, ртути $(\mathrm{r}=0,75)$. В печени - с марганцем $(\mathrm{r}=0,74)$, никелем $(\mathrm{r}=0,86)$, медью $(\mathrm{r}=0,79)$, свинцом $(\mathrm{r}=0,58)$. В почках c серой $(\mathrm{r}=0,81)$, марганцем $(\mathrm{r}=0,71)$, никелем $(\mathrm{r}=0,62)$, свинцом $(\mathrm{r}=0,91)$. В сердце - с серой $(\mathrm{r}=0,74)$, хлоридами $(\mathrm{r}=0,77)$, бромом $(\mathrm{r}=0,79)$, ртутью $(\mathrm{r}=0,90)$. В щитовидной железе - с марганцем $(\mathrm{r}=0,92)$, медью $(\mathrm{r}=-0,92)$, цинком $(\mathrm{r}=0,83)$, свинцом $(\mathrm{r}=0,63)$.

Таким образом, элементы, связанные с поступлением мышьяка в органы только прямыми связями, сера (лёгкие, мышцы, почки, сердце), хлориды (сердце), титан (мышцы), никель (печень, почки), цинк (щитовидная железа), а только обратными - молибден (кровь, лёгкие), медь (мышцы, печень, щитовидная железа), хром (мышцы). И только марганец (прямая связь в печени и почках и обратная в щитовидной железе) и свинец (прямая связь в лёгких, печени, почках, щитовидной железе и обратная в крови) имеют как прямые, так и обратные связи с содержанием мышьяка.

Если исходить из того, что прямая связь содержания элемента с мышьяком - это отражение активности восстановительных процессов, а обратная зависимость характеризует проявление токсичности и вытеснение мышьяком биологически активных элементов, то можно отметить, что только в почках и сердце испытанные 
дозы мышьяка не привели к эффектам токсического действия. Проявление токсичности мышьяка в отношении других органов выражалось в нарушении про- цессов с участием молибдена и свинца в крови, молибдена в лёгких, хрома и меди в мышцах, меди в печени, меди и марганца в щитовидной железе.

Таблица 5. Связь содержания мышьяка с другими элементами в тканях органов белых крыс линии Вистар при подострой (3 недели) пероральной затравке мышьяком и сурьмой в дозах 0,015 и 0,061мг/кг/сут соответственно и 4-х недельном восстановительном периоде

Table 5. Association of arsenic content with other elements in the tissues of the organs of white Wistar rats with subacute (3 weeks) oral seeding with arsenic and antimony in doses of 0,015 and 0,061 $\mathrm{mg} / \mathrm{kg} /$ day, respectively, and in a 4-week recovery period

\begin{tabular}{|c|c|c|c|c|c|c|c|c|c|c|c|c|c|c|}
\hline $\begin{array}{l}\text { Орган } \\
\text { Organ }\end{array}$ & $\begin{array}{c}\text { Статистический параметр } \\
\text { Statistical parameter } \\
\end{array}$ & S & $\mathrm{Cl}$ & $\mathrm{Ti}$ & $\mathrm{Cr}$ & $\mathrm{Mn}$ & $\mathrm{Ni}$ & $\mathrm{Cu}$ & $\mathrm{Zn}$ & $\mathrm{Br}$ & Mo & $\mathrm{Hg}$ & $\mathrm{Pb}$ & $\mathrm{Sb}$ \\
\hline \multirow{2}{*}{$\begin{array}{l}\text { Кровь } \\
\text { Blood }\end{array}$} & $r$ & $-0,02$ & 0,55 & $-0,26 \mid$ & $-0,10$ & $-0,52$ & $-0,63$ & $-0,19$ & $-0,08$ & $-0,29$ & $-0,682$ & $-0,04$ & $-0,81$ & 0,98 \\
\hline & $\mathrm{p}$ & - & - & - & - & - & - & - & - & - & $<0.05$ & - & $<0.05$ & $<0.05$ \\
\hline \multirow{2}{*}{$\begin{array}{l}\text { Лёгкие } \\
\text { Lungs }\end{array}$} & $\mathrm{r}$ & 0,70 & 0,30 & 0,54 & $-0,17$ & 0,14 & 0,02 & $-0,17$ & $-0,58$ & 0,10 & $-0,75$ & 0,003 & 0,82 & - \\
\hline & $\mathrm{p}$ & $<0.05$ & - & - & - & - & - & - & - & - & $<0,05$ & - & $<0.05$ & - \\
\hline \multirow{2}{*}{$\begin{array}{l}\text { Mышцы } \\
\text { Muscle }\end{array}$} & $\mathrm{r}$ & 0,82 & 0,45 & $\begin{array}{l}0,77 \\
\end{array}$ & $-0,91$ & $-0,40$ & $-0,51$ & $-0,73$ & $-0,40$ & $-0,20$ & 0,45 & 0,75 & $\begin{array}{l}0,47 \\
\end{array}$ & - \\
\hline & p & $<0.05$ & - & $<0.05$ & $<0,05$ & - & - & $<0,05$ & - & - & - & $<0.05$ & - & - \\
\hline \multirow{2}{*}{$\begin{array}{l}\text { Печень } \\
\text { Liver }\end{array}$} & $\mathrm{r}$ & 0,45 & 0,26 & 0,11 & 0,45 & 0,74 & 0,86 & $-0,79$ & $-0,16$ & $-0,14$ & $-0,31$ & $\begin{array}{l}\text { Н.д. } \\
\text { N.d. }\end{array}$ & 0,58 & - \\
\hline & $\mathrm{p}$ & - & - & - & - & $<0,05$ & $<0.05$ & $<0,05$ & - & - & - & $\begin{array}{l}\text { Н.д. } \\
\text { N.d. }\end{array}$ & 0,09 & - \\
\hline \multirow{2}{*}{$\begin{array}{l}\text { Почки } \\
\text { Kidney }\end{array}$} & $r$ & 0,81 & 0,38 & 0,33 & 0,28 & 0,71 & 0,62 & $-0,29$ & 0,03 & $-0,05$ & $-0,37$ & $-0,15$ & 0,91 & - \\
\hline & $\mathrm{p}$ & $<0.05$ & - & - & - & $<0.05$ & 0,07 & - & - & - & - & - & $<0.05$ & - \\
\hline \multirow{2}{*}{$\begin{array}{c}\text { Сердце } \\
\text { Heart }\end{array}$} & $\mathrm{r}$ & 0,74 & 0,77 & $-0,25$ & $-0,31$ & $-0,03$ & $-0,29$ & $-0,54$ & 0,18 & $\begin{array}{l}0,79 \\
\end{array}$ & $-0,37$ & 0,90 & $-0,39$ & - \\
\hline & $p$ & $<0.05$ & $<0.05$ & \begin{tabular}{|l|}
- \\
\end{tabular} & - & - & - & - & - & $<0.05$ & - & $<0.05$ & - & - \\
\hline \multirow{2}{*}{$\begin{array}{c}\text { Щитовидная железа } \\
\text { Thyroid } \\
\end{array}$} & $\mathrm{r}$ & $-0,49$ & 0,22 & 0,24 & 0,06 & $-0,92$ & $-0,61$ & $-0,92$ & 0,83 & 0,06 & $-0,45$ & $-0,54$ & 0,63 & - \\
\hline & $\mathrm{p}$ & - & - & - & - & $<0,05$ & - & $<0,05$ & $<0.05$ & - & - & - & 0 & - \\
\hline
\end{tabular}

Примечание: Н.д. - нет данных

Note: N.d. - not determined.

Следовательно, подострое пероральное комбинированное воздействие сурьмы и мышьяка в дозах 0,061 и 0,015 мг/кг/сут вызывает элементный дисбаланс в органах: молибдена и свинца в крови, молибдена в лёгких, хрома и меди в мышцах, меди в печени, меди и марганца в щитовидной железе.

\section{Заключение}

1. Маркёрами экспозиции перорального поступления в теплокровный организм соединений мышьяка является увеличение его концентрации в тканях всех исследованных органов: печени, почек, сердца, крови, легких, щитовидной железы; сурьма накапливалась в крови.

2. Маркёрами ответа организма на подострое пероральное поступление соединений мышьяка и сурьмы служат:

- уменьшение концентрации элементов в крови (на 18-38 \% - хром, медь, железо, марганец, молибден, никель, титан);

\section{СПИСОК ЛИТЕРАТУРЫ}

1. Salomons W. Environmental impact of metals derived from mining activities: Processes, predictions, prevention // Journal of Geochemical Exploration. - 1995. - V. 52. - № 1-2. - P. 5-23.

2. The hydrogeochemistry of the Nickel Rim mine tailings impoundment, Sudbury, Ontario / R. Johnson, D. Blowes, W. Robertson, J. Jambor // Journal of Contaminant Hydrology. 2000. - V. 41. - № 1-2. - P. 49-80.

3. Akcil A., Koldas S. Acid Mine Drainage (AMD): causes, treatment and case studies // Journal of Cleaner Production. 2006. - V. 14. - № 12-13. - P. 1139-1145.

4. Lottermoser B. Mine wastes. - Berlin, Heidelberg: Springer, 2003. $-311 \mathrm{p}$.
- элементный дисбаланс в органах: молибдена и свинца в крови, молибдена в лёгких, хрома и меди в мышцах, меди в печени, меди и марганца в щитовидной железе.

3. Скорость элиминации мышьяка и сурьмы преобладает над абсорбцией в ряду органов: для мышьяка - кровь, печень, почки, щитовидная железа, сердце, лёгкие; для сурьмы - мышцы, кровь.

Работа выполнена при финансовой поддержке РНФ (грант № 19-17-00134).

\section{Конфликт интересов отсутствует.}

Авторы выражают слова искренней благодарности главе Комсомольского поселения Васильеву А.М. за поддержку и оказание содействия в планировании и организачии данного исследования, ректору ФГБОУ ВО «НГМУ» профессору, д.м.н. Маринкину И.О. за предоставление экспериментальных животных, оборудования и помещений вивария.

5. Hydrological modeling of a watershed affected by acid mine drainage (Odiel River, SW Spain). Assessment of the pollutant contributing areas / L. Galván, M. Olías, C. Cánovas, A. Sarmiento, J. Nieto // Journal of Hydrology. - 2016. - V. 540. - P. 196-206.

6. Ковальский В.В. 60 лет биогеохимии в СССР. Биогеохимическое районирование и геохимическая экология // Тр. Биогеохим. лаб. - М.: Наука, 1985. - Т. 20. - С. 5-24.

7. Корнеева Т.В., Юркевич Н.В., Аминов П.Г. Геохимические особенности миграционных потоков в зоне влияния горнопромышленного техногенеза (г. Медногорск) // Известия Томского политехнического университета. Инжиниринг георесурсов. -2017 . - Т. 328. - № 2. - С. 85-94.

8. Огудов А.С., Турбинский В.В. Комплексные геохимические исследования в проектировании санитарно-защитных зон гор- 
но-обогатительных комбинатов // ИнтерЭкспо Гео - Сибирь. 2017. - № 3. - C. 210-214.

9. Трофимович Е.М., Гурвич С.М. Охрана водных объектов при добыче и обогащении руд и углей. - М.: Недра, 1985. - 192 с.

10. Geochemical and mineralogical aspects of sulfide mine tailings / M. Lindsay, M. Moncur, J. Bain, J. Jambor, C. Ptacek, D. Blowes // Applied Geochemistry. - 2015. - V. 57. - P. 157-177

11. Иванов В.В., Малинецкий Г.Г. Россия: XXI век. Стратегия прорыва: Технологии. Образование. Наука. - М.: ЛЕНАНД, 2016. $-304 \mathrm{c}$.

12. Копанев В.А., Гинзбург Э.Х., Семенова В.Н. Метод вероятностной оценки токсического эффекта / отв. ред. Ю.С. Каган. - Новосибирск: Наука: Сиб. отд-ние, 1988. - 122 с.

13. Ермаков В.В. Геохимическая экология и биогеохимические критерии оценки экологического состояния таксонов биосферы // Геохимия. - 2015. - № 3. - С. 203-221.

14. Nagajyoti P., Lee K., Sreekanth T. Heavy metals, occurrence and toxicity for plants: a review // Environmental Chemistry Letters. 2010. - V. 8. - № 3. - P. 199-216.

15. Health risk from heavy metals via consumption of food crops in the vicinity of Dabaoshan mine, South China / P. Zhuang, M. McBride, H. Xia, N. Li, Z. Li // Science of The Total Environment. - 2009. - V. 407. - № 5. - P. 1551-1561.

16. Биогеохимическая дифференциация живого вещества и биоразнообразия в условиях ардонского полиметаллического субрегиона биосферы / В.В. Ермаков, С.Ф. Тютиков, А.П. Дегтярёв, В.А. Сафонов, В.В. Данилова, С.Д. Хушвахтова, У.А. Гуляева, Е.В. Кречетова Геохимия. - 2018. -№4.- С. 336-350.

17. Актуальные проблемы профилактической медицины в Уральском регионе / В.Б. Гурвич, Э.Г. Плотко, С.В. Кузмин, К.П. Селянкина, В.В. Рыжов, Н.П. Макаренко, В.Г. Надеенко // Сборник научных трудов и научно-практических работ, посвященный 80-летию госсанэпидслужбы России. - Асбест: ГОУП Асбестов. тип., 2002. -С. 76-81.

18. Ермаков В.В., Ковальский Ю.В. Техногенез и биогеохимическая эволюция таксонов биосферы // Биогеохимия техногенеза и современные проблемы геохимической экологии (в двух томах). - Барнаул: Институт водных и экологических проблем CO PAH, 2015. - T. 1. - C. 8-12.

19. Зайцева Н.В., Устинова О.Ю. Медико-профилактические технологии для задач управления риском нарушений здоровья населения, ассоциированных с воздействием факторов среды обитания // Фундаментальные исследования. - 2014. - № 10-4. - С. 665-670.

20. Химический элементный состав органов и тканей человека и его экологическое значение / Л.П. Рихванов, Н.В. Барановская, Т.Н. Игнатова, А.Ф. Судыко, Г.П. Сандимирова, Н.Н. Пахомова // Геохимия. - 2011. - № 7. - С. 779-784.

21. Геохимические особенности техногенного озера, содержащего отходы цианирования золото-арсенопирит-кварцевых руд / О.Л. Гаськова, С.Б. Бортникова, А.А. Айриянц, Ю.П. Колмогоров, М.В. Пашков // Геохимия. - 2000. - № 3. - С. 317-328

22. Characterization of a gold extraction plant environment in assessing the hazardous nature of accumulated wastes (Kemerovo region, Russia) / S. Bortnikova, V. Olenchenko, O. Gaskova, N. Yurkevich, N. Abrosimova, E. Shevko, A. Edelev, T. Korneeva
I. Provornaya, L. Eder // Applied Geochemistry. - 2018. - V. 93. P. $145-157$.

23. Гигиенические нормативы ГН 2.1.5.1315-03. Предельно допустимые концентрации (ПДК) химических веществ в воде водных объектов хозяйственно-питьевого и культурно-бытового водопользования. - М.: Минюст РФ, 2003. -468 с.

24. Определение основных компонентов силикатных горных пород рентгеноспектральным флуоресцентным методом. Инструкция НСАМ 202РС / И.В. Сорокин, В.А. Симаков, Л.И. Земцова, Б.А. Цимошенко. - М.: ВИМС, 1983. - 29 с.

25. Baryshev V.B., Kulipanov G.N., Scrinsky A.N. X-ray fluorescence elemental analysis using synchronous radiation // Handbook of Synchrotron Radiation / Eds. G. Brown, D. Moncton. - Amsterdam: Elsevier, 1991. - V. 3. - P. 639-641.

26. NIST. Standard Reference Materials. Catalog 1995-96. NIST Special Publication 260 / Ed. by N.M. Trahey. - Gaithersburg: National Institute of Standards and Technology, 1995. - 167 p.

27. Руководство по оценке риска для здоровья населения при воздействии химических веществ, загрязняющих окружающую среду. Р 2.1.10.1920-04. - М.: Федеральный центр госсанэпиднадзора Минздрава России, 2004. - 143 с.

28. Современное представление о токсикодинамике и токсикокинетике. URL: http://myzooplanet.ru/farmakologiya-toksikologiyaveterinarnaya/sovremennoe-predstavlenie-toksikodinamike15583.html (дата обращения 22.12.2018).

29. Землянова М.А., Кольдибекова Ю.В. Современные подходы к оценке нарушений метаболизма ксенобиотиков при поступлении в организм из внешней среды // Экология человека. 2012. - № 8. - C. 8-14.

30. Макдермотт М. Секреты эндокринологии / Пер. с англ. - М.; СПб: Бином, Невский диалект, 2000. - 464 с.

31. Турбинский В.В., Бортникова С.Б. О соотношении мышьяка и сурьмы в биогеохимических провинциях как факторов риска здоровью // Анализ риска здоровью. - 2018. - № 3. - С. 136-143.

32. Antimony speciation in the environment: recent advances in understanding the biogeochemical processes and ecological effects / M. He, N. Wang, X. Long, C. Zhang, C. Ma, Q. Zhong, A. Wang, Y. Wang, A. Pervaiz, J. Shan // Journal of Environmental Sciences. - 2019. - V. 75. - P. 14-39.

33. Ткачева Т.А., Карпухина Е.А., Каютина С.В. Оценка потенциального риска развития вредных эффектов при воздействии химического фактора на основе различных токсикологических параметров // Медицина труда и промышленная экология. - 2008. - № 6. - С. 69-74.

34. Monomethylated trivalent arsenic species disrupt steroid receptor interactions with their DNA response elements at non-cytotoxic cellular concentrations / J. Gosse, V. Taylor, B. Jackson, J. Hamilton, J. Bodwell // Journal of Applied Toxicology. 2013. - V. 34. - № 5. - P. 498-505.

35. Taylor S.R., McLennan S.M. The continental crust: its composition and evolution. - United States, 1985. - 312 p.

Поступила 13.03.2020 2.

\section{Информация об авторах}

Tурбинский В.В., доктор медицинских наук, доцент, профессор кафедры гигиены и экологии Новосибирскийого государственного медицинского университета Минздрава России.

Бортникова С.Б., доктор геолого-минералогических наук, профессор, заведующая лабораторией геоэлектрохимии Института нефтегазовой геологии и геофизики им. А.А. Трофимука Сибирского отделения Российской академии наук.

Никифорова Н.Г., доктор биологических наук, профессор, заведующая кафедрой гигиены и экологии Новосибирского государственного медицинского университета Минздрава России.

Оzудов A.C., кандидат медицинских наук, заведующий отделом токсикологии Новосибирского научноисследовательского института гигиены Роспотребнадзора.

Айзман Р.И., доктор биологических наук, профессор, заведующий кафедрой анатомии, физиологии и безопасности жизнедеятельности Новосибирского государственного педагогического университета.

Корнеева T.B., кандидат геолого-минералогических наук, научный сотрудник лаборатории геоэлектрохимии Института нефтегазовой геологии и геофизики им. А.А. Трофимука СО РАН.

Франовский С.Ю., аспирант факультета почвоведения Московского государственного университета им. М.В. Ломоносова. 
UDC 556.04

\section{MARKERS OF BIOGEOCHEMICAL MONITORING IN THE SULPHIDE ORES TAILINGS AREA}

\author{
Viktor V. Turbinskiy ${ }^{1}$, \\ vvturbinski@mail.ru
}

\author{
Svetlana B. Bortnikova², \\ BortnikovaSB@ipgg.sbras.ru \\ Natalya G. Nikiforova ${ }^{1}$, \\ natnik@ngs.ru
}

\author{
Roman I. Aizman 4 , \\ aizman.roman@yandex.ru
}

\section{Tatyana V. Korneeva ${ }^{2}$,} korneevatv@ipgg.sbras.ru

Sergey Yu. Franovsky 5 , franovsky.sergey@gmail.com

\section{Alexandr S. Ogudov ${ }^{3}$,} ogudov.tox@yandex.ru

${ }^{1}$ Novosibirsk State Medical University of the Ministry of Health of Russia, 52, Krasny avenue, Novosibirsk, 630091, Russia.

2 Trofimuk Institute of Petroleum Geology and Geophysics SB RAS,

3, Koptyug avenue, Novosibirsk, 630090, Russia.

${ }^{3}$ Novosibirsk Scientific Research Institute of Hygiene, Rospotrebnadzor, 7, Parkhomenko street, Novosibirsk, 630108, Russia.

${ }^{4}$ Novosibirsk State Pedagogical University, 28, Vilyuyskaya street, Novosibirsk, 630126, Russia.

5 Lomonosov Moscow State University, bld. 12, 1, Leninskie Gory, Moscow, 119991, Russia.

Relevance. Sulfide mining tailings as a source of chemical element pollution of the environment are a significant risk to household water use and public health. On the example of the sulfide tailings impoundment at the Komsomolsk settlement (Kemerovo region), containing cyanidation wastes of gold-arsenopyrite-quartz ores, the effects of arsenic and antimony on warm-blooded animals is shown. The elemental markers of wastewater toxicity were substantiated in the experiment on laboratory animals.

The aim of the research is to substantiate the environmental monitoring markers and warm-blooded organisms under the risk of exposure to tailings of sulfide ore dressing waste.

The methods of the research included sampling water from a hydraulic dump to use it as a drink for experimental animals (male Wistar white rats weighing 250-290 g). Water was analyzed for a number of chemical elements by ICP-AES. Further, after preparation of the animals, the elemental composition of the tissues was determined. The analysis was performed by the XRD-SI method at the VEPP-3 elemental analysis station (INP SB RAS). The emission spectra were processed using the AXIL program.

The results. According to the elemental composition of tissues of organs - liver, kidneys, heart, lungs, thyroid gland - of male white Wistar rats, the markers of exposure of the combined action of antimony and arsenic in doses of 42-61 and 10-15 $\mu \mathrm{g} / \mathrm{kg} /$ day, respectively, were determined. It was found that the effect of antimony and arsenic in the doses studied is accompanied by their accumulation in the tissues of animal organs, and changes in the balance of other elements - zinc, copper, iron, manganese, strontium, nickel, and lead. Coefficients of absorption and elimination of arsenic and antimony for tissues of internal organs at oral intake were calculated and the correlation of elements in different organs was shown.

Key words:

Sulfide ores, tailings, drainage waters, antimony, arsenic, drinking water, tissues of organs, absorption constant, elimination constant.

The research was financially supported by the RSF (grant no. 19-17-00134).

There is no conflict of interests.

The authors express thanks to A.M. Vasilyev, the head of Komsomolsky settlement for support and assistance in planning and arranging the research, to I.O. Marinkin, the rector of NGMU, professor, Dr. Sc., for the experimental animals, equipment and vivarium.

\section{REFERENCES}

1. Salomons W. Environmental impact of metals derived from mining activities: Processes, predictions, prevention. Journal of Geochemical Exploration, 1995, vol. 52, no. 1-2, pp. 5-23.

2. Johnson R., Blowes D., Robertson W., Jambor J. The hydrogeochemistry of the Nickel Rim mine tailings impoundment, Sudbury, Ontario. Journal of Contaminant Hydrology, 2000, vol. 41, no. 1-2, pp. $49-80$.
3. Akcil A., Koldas S. Acid Mine Drainage (AMD): causes, treatment and case studies. Journal of Cleaner Production, 2006, vol. 14, no. 12-13, pp. 1139-1145.

4. Lottermoser B. Mine Wastes. Berlin; Heidelberg, Springer, 2003. $311 \mathrm{p}$.

5. Galván L., Olías M., Cánovas C., Sarmiento A., Nieto J. Hydrological modeling of a watershed affected by acid mine drainage 
(Odiel River, SW Spain). Assessment of the pollutant contributing areas. Journal of Hydrology, 2016, vol. 540, pp. 196-206.

6. Kovalskiy V.V. 60 let biogeokhimii v SSSR. Biogeokhimicheskoe rayonirovanie i geokhimicheskaya ekologiya [60 years of biogeochemistry in the USSR. Biogeochemical zoning and geochemical ecology]. Tr. Biogeokhim. lab. Moscow, Nauka Publ., 1985. Vol. 20, pp. 5-24.

7. Korneeva T.V., Yurkevich N.V., Aminov P.G. Geochemical features of migration flows in the impact zone of mining technogenesis (Mednogorsk). Bulletin of the Tomsk Polytechnic University. Geo Assets Engineering, 2017, vol. 328, no. 2, pp. 85-94. In Rus.

8. Ogudov A.S., Turbinsky V.V. Integrated geochemical studies in the design of sanitary protection zones of mining and processing plants. InterExpo Geo - Siberia, 2017, no. 3, pp. 210-214.

9. Trofimovich E.M., Gurvich S.M. Okhrana vodnykh obyektov pri dobyche $i$ obogashchenii rud $i$ ugley [Protection of water bodies during the extraction and concentration of ores and coal]. Moscow, Nedra Publ., 1985. 192 p.

10. Lindsay M., Moncur M., Bain J., Jambor J., Ptacek C., Blowes D. Geochemical and mineralogical aspects of sulfide mine tailings. Applied Geochemistry, 2015, vol. 57, pp. 157-177.

11. Ivanov V.V., Malinetskiy G.G. Rossiya: XXI vek. Strategiya proryva: Tekhnologii. Obrazovaniye. Nauka [Russia: XXI century. Breakthrough Strategy: Technology. Education. Science]. Moscow, LENAND Publ., 2016. 304 p.

12. Kopanev V.A., Ginzburg E.Kh., Semenova V.N. Metod veroyatnostnoy otsenki toksicheskogo effekta [The method of probabilistic assessment of toxic effect]. Ed. by Yu.S. Kagan. Novosibirsk, Nauka Publ., 1988. 122 p.

13. Ermakov V.V. Geochemical ecology and biogeochemical criteria for assessing the ecological state of biosphere taxa. Geochemistry, 2015, no. 3, pp. 203-221. In Rus.

14. Nagajyoti P., Lee K., Sreekanth T. Heavy metals, occurrence and toxicity for plants: a review. Environmental Chemistry Letters, 2010, vol. 8, no. 3, pp. 199-216.

15. Zhuang P., McBride M., Xia H., Li N., Li Z. Health risk from heavy metals via consumption of food crops in the vicinity of Dabaoshan mine, South China. Science of the Total Environment, 2009, vol. 407, no. 5, pp. 1551-1561.

16. Ermakov V., Tyutikov S., Degtyarev A., Safonov V., Danilova V., Khushvakhtova S., Gulyaeva U., Krechetova E. Biogeochemical differentiation of living matter and biodiversity in the Ardon polymetallic subregion of the biosphere. Geochemistry International, 2018, vol. 56, no. 4, pp. 318-331. In Rus.

17. Gurvich V.B., Plotko E.G., Kuzmin S.V., Selyankina K.P., Ryzhov V.V., Makarenko N.P., Nadeenko V.G. Aktualnye problemy profilakticheskoy meditsiny $\mathrm{v}$ Uralskom regione [Actual problems of preventive medicine in the Ural region]. Sbornik nauchnykh trudov i nauchno-prakticheskikh rabot, posvyashchenny 80-letiyu gossanepidsluzhby Rossii [Proc. of scientific work dedicated to the $80^{\text {th }}$ anniversary of State Sanitary and Epidemiological Service of the Russian Federation]. Asbest, GUP Asbestov. typ., 2002. pp. 76-81.

18. Ermakov V.V., Kovalskiy Yu.V. Tekhnogenez i biogeokhimicheskaya evolyutsiya taksonov biosfery [Technogenesis and biogeochemical evolution of biosphere taxa]. Biogeokhimiya tekhnogeneza i sovremennye problemy geokhimicheskoy ekologii [Biogeochemistry of technogenesis and modern problems of geochemical ecology]. Barnaul, Institute of Water and Environmental Problems SB RAS, 2015. Vol. 1, pp. 8-12.

19. Zaytseva N.V., Ustinova O.Yu. Medical and preventive technologies for the management of health disorders associated with the environmental impact. Fundamental research, 2014, no. 10 (P. 4), pp. 665-670. In Rus.

20. Rikhanov L., Baranovskaya N., Ignatova T., Sudyko A., Sandimirova G., Pakhomova N. Trace elements in human organs and tissues and their significance for environmental monitoring. Geochemistry International, 2011, vol. 49, no. 7, pp. 738-742. In Rus.

21. Gaskova O.L., Bortnikova S.B. Ayriyants A.A., Kolmogorov Yu.P., Pashkov M.V. Geokhimicheskie osobennosti tekhnogennogo ozera, soderzhashchego otkhody tsianirovaniya zoloto-arsenopiritkvartsevykh rud [Geochemical features of a technogenic lake con- taining cyanidation wastes of gold-arsenopyrite-quartz ores]. Geokhimiya, 2000, no. 3, pp. 317-328.

22. Bortnikova S., Olenchenko V., Gaskova O., Yurkevich N., Abrosimova N., Shevko E., Edelev A., Korneeva T., Provornaya I., Eder L. Characterization of a gold extraction plant environment in assessing the hazardous nature of accumulated wastes (Kemerovo region, Russia). Applied Geochemistry, 2018, vol. 93, pp. 145-157.

23. Gigienicheskie normativy GN 2.1.5.1315-03. Predelno dopustimye kontsentratsii $(P D K)$ khimicheskikh veshchestv $v$ vode vodnykh obyektov khozyaystvenno-pityevogo i kulturno-bytovogo vodopolzovaniya [Hygienic standards of GN 2.1.5.1315-03. The maximum permissible concentration of chemicals in the water of water bodies of domestic, drinking, and cultural and domestic water use]. Moscow, Minyust RF Publ., 2003. 468 p.

24. Sorokin I.V., Simakov V.A., Zemtsova L.I., Tsimoshenko B.A. Opredelenie osnovnykh komponentov silikatnykh gornykh porod rentgenospektralnym fluorestsentnym metodom. Instruktsiya NSAM 202RS [Determination of the main components of silicate rocks by the X-ray fluorescence method. Instruction NSAM 202RS]. Moscow, VIMS Publ., 1983. 29 p.

25. Baryshev V.B., Kulipanov G.N., Scrinsky A.N. X-ray fluorescence elemental analysis using synchronous radiation. Handbook of Synchrotron Radiation. Eds. G. Brown, D. Moncton. Amsterdam, Elsevier, 1991. Vol. 3, pp. 639-641.

26. NIST. Standard Reference Materials. Catalog 1995-96. NIST Special Publication 260. Ed. by N.M. Trahey. Gaithersburg, National Institute of Standards and Technology, 1995. $167 \mathrm{p}$.

27. Rukovodstvo po otsenke riska dlya zdorovya naseleniya pri vozdeystvii khimicheskikh veshchestv, zagryaznyayushchikh okruzhayushchuyu sredu. Rukovodstvo. R 2.1.10.1920-04 [Guidance on assessing public health risk from exposure to chemicals that pollute the environment. Leadership. R 2.1.10.1920-04]. Moscow, Federal Center for State Sanitary and Epidemiological Supervision of the Ministry of Health of Russia, 2004. 143 p.

28. Sovremennoe predstavlenie o toksikodinamike $i$ toksikokinetike [Modern understanding of toxicodynamics and toxicokinetics]. Available at: http://myzooplanet.ru/farmakologiya-toksikologiyaveterinarnaya/sovremennoe-predstavlenie-toksikodinamike15583.html (accessed 22 December 2018)

29. Zemlyanova M.A., Koldibekova Yu.V. Sovremennyye podkhody $\mathrm{k}$ otsenke narusheniy metabolizma ksenobiotikov pri postuplenii $\mathrm{v}$ organizm iz vneshney sredy [Modern approaches to assessing metabolic disorders of xenobiotics when ingested from the external environment]. Ekologiya cheloveka, 2012, no. 8, pp.8-14.

30. Makdermott M. Sekrety endokrinologii [Endocrinology secrets]. Moscow, St-Petersburg, Binom, Nevskiy dialekt Publ., 2000. $464 \mathrm{p}$.

31. Turbinsky V., Bortnikova S. O sootnoschenii myshyaka i surmi v biogeochimicheskikh provintsiaykh kak faktor riska zdorovyu [Proportions of arsenic and antimony in biogeochemical provinces as health risk factors]. Health Risk Analysis, 2018, no. 3, pp. 136-143. In Rus.

32. He M., Wang N., Long X., Zhang C., Ma C., Zhong Q., Wang A., Wang Y., Pervaiz A., Shan J. Antimony speciation in the environment: Recent advances in understanding the biogeochemical processes and ecological effects. Journal of Environmental Sciences, 2019, vol. 75, pp. 14-39.

33. Tkacheva T.A., Karpukhina E.A., Kayutina S.V. Otsenka potentsialnogo riska razvitiya vrednykh effektov pri vozdeystvii khimicheskogo faktora na osnove razlichnykh toksikologicheskikh parametrov [Assessment of potential risk of harmful effects when exposed to a chemical factor based on various toxicological parameters]. Meditsina truda i promyshlennaya ekologiya, 2008, no. 6, pp. 69-74.

34. Gosse J., Taylor V., Jackson B., Hamilton J., Bodwell J. Monomethylated trivalent arsenic species disrupt steroid receptor interactions with their DNA response elements at non-cytotoxic cellular concentrations. Journal of Applied Toxicology, 2013, vol. 34, no. 5, pp. 498-505.

35. Taylor S.R., McLennan S.M. The continental crust: its composition and evolution. United States, 1985. $312 \mathrm{p}$ 
Information about the authors

Viktor V. Turbinskiy, Dr. Sc., associate professor, professor, Novosibirsk State Medical University of the Ministry of Health of Russia.

Svetlana B. Bortnikova, Dr. Sc., professor, head of laboratory, Trofimuk Institute of Petroleum Geology and Geophysics SB RAS.

Natalya G. Nikiforova, Dr. Sc., professor, head of the Department of hygiene and ecology, Novosibirsk State Medical University of the Ministry of Health of Russia.

Alexandr S. Ogudov, Cand. Sc., head of the Department of toxicology, Novosibirsk Scientific Research Institute of Hygiene, Rospotrebnadzor .

Roman I. Aizman, Dr. Sc., professor, head of the Department of anatomy, physiology and life safety, Novosibirsk State Pedagogical University.

Tatyana V. Korneeva, Cand. Sc., researcher, Trofimuk Institute of Petroleum Geology and Geophysics SB RAS.

Sergey Yu. Franovsky, postgraduate student, Lomonosov Moscow State University. 